УДК 94(497.11):930"2007"(049.32)

94(497.11)(049.32)

DOI https://doi.org/10.31212/tokovi.2021.3.lam.277-295

Научна критика и полемика

Примљена: 17. 5. 2021.

Прихваћена: 12.11. 2021.

\begin{abstract}
John R. LAMPE
Department of History, University of Maryland, Woodrow Wilson International Center for Scholars, Washington, DC jrlampe@umd.edu
\end{abstract}

\title{
Serbia and Southeastern Europe between Global and East European History
}

\begin{abstract}
Drawing on a half century of Balkan research and publication that started in Belgrade, John Lampe reviews three new Western histories of the region and their attention to Serbia from prominent Western historians. Germany's Calic examines only Southeastern Europe, while Connelly from the US and Bideleux and Jeffries from the UK include the Balkans in their volumes on Eastern Europe.

KEY WORDS: Serbia, Yugoslavia, Southeastern Europe, Global History, Regional History, Marie-Janine Calic, John Connelly, Robert Bideleux, Ian Jeffries.
\end{abstract}

Marie-Janine Calic. The Great Caldron, A History of Southeastern Europe.

Cambridge, Mass: Harvard University Press, 2019. John Connelly. From Peoples into Nations, A History of Eastern Europe. Princeton, NJ: Princeton University Press, 2020. Robert Bideleux and Ian Jeffries. A History of Eastern Europe, Crisis and Change, Second edition. Oxford and New York: Routledge, 2007.

My own interest in Serbian history began not long after the publication in 1958 of what stood until the Calic volume as the only comprehensive study of the wider region back to the Ottoman conquest and before. Leften Stavrianos, The Balkans since 1453 (1958) was reprinted as recently as 2000. Guiding my doctoral research in Belgrade on Serbia's financial history before 1914, Danica Milić introduced me to the impor- 
tance of European archival evidence for Serbian economic as well as diplomatic history for herself and her colleagues. I went on from there to apply the same sources in Vienna, Paris and London to the wider region with Marvin Jackson in our Balkan Economic History. 1550-1950, From Imperial Borderlands to Developing Nations (1982). By the 1980s, Serbian historians were applying the same emphasis and international research to the first Yugoslavia. Evidence of European recognition was as important as the Marxist framework which the Great Depression appeared to vindicate. My own research added urban history, Belgrade included, to economic history and then to political parties, elections and institutions across the region. Branislav Gligorijević (1979) pioneered a Serbian turn to the parliamentary politics of the 1920s, while Todor Stojkov examined the authoritarian regime of the 1930s (1985).

Now, 30 years after Serbia saw its connection to the second Yugoslavia end in dissolution, the European credentials, to which pre-1914 Serbia and both Yugoslavia's aspired, have not recovered from the civil wars and international intervention of the 1990s. Its younger historians are facing and sometimes overcoming a popular temptation to read back a sense of foreign victimization into Serbian history. This review examines the attention it receives in major new Western histories of the wider region. Their authors are from Germany, the United States and the United Kingdom, Wales to be specific. Let me emphasize that their own ethnic origin has no discernable effect on their analysis or sources. This is particularly important for Calic, whose Croatian roots have been raised to criticize her earlier writing on the wars of dissolution. Dismissing this stereotypical assumption here, the assumptions underlying her approach are nonetheless - different from Connelly's and his from Bideleux and Jeffries. Let us review their frameworks before turning to their attentions to Serbia, its neighbors and Yugoslavia.

All three are based on secondary sources, reputable and well chosen. Calic's bibliography is more than twice as long as Bideleux and Jeffries and includes more citations from scholarship in regional languages. Connelly's book has no bibliography but its ample footnotes draw on Anglo-American and German scholarship. All three deserve credit for reaching back to initial settlement and Christian conversion, rather than starting with the Ottoman conquest as so much Western scholarship, including my own, has done. But there, the similarities end.

Calic announces in her Introduction that she follows the "new consensus" (p. 3) around global history. It assumes the overriding importance 
of contact zones and transnational spaces. The rise of international trade is welcomed but capitalist markets and regional inequities are not. She discounts the focus on the nation-state and the drive for European modernization that has informed the mainstream of regional as well as German and Anglo-American scholarship on Southeastern Europe, including mine (Lampe, 2014). She celebrates instead the recent wider interest in imperial and post-colonial history. For our region, global history promotes the more positive treatments of Habsburg hegemony in Bosnia-Herzegovina (Okey, 2007) and in all of the borderlands (Judson, 2016). Her title's choice of Southeastern Europe rather than the Balkans is a German practice of much longer standing. Her own scholarship dates from a valuable social history of Serbia in German (1994) to the present volume, now translated from German. Social history serves her well in tracking populations and societies across the two millennia, paying special attention to the migrations and commercial centers that promoted transnational mixing. Ports also opened the way to more global interaction than recognized in previous scholarship. The sweep of this social, economic and cultural history usefully portrays a region more connected to the wider world than the old stereotype that made "Balkans" a synonym for disconnection and dysfunction. But there are omissions in such an account, as we shall see, partly filled by the other two volumes.

Connelly's volume celebrates the positive connection of nations to states, not to the wider world. As may be gathered from the title Peoples into Nations, he follows the region's initial population from their survival between the early modern empires to the national movements that finally freed them. His approach to the nation over time coincides with a recent new study of German history (Walser Smith, 2020). Connelly's Eastern Europe is read back from the Cold War as the space and also the crossroads between the Russian, Prussian, Habsburg and Ottoman Empires. His own scholarship began with the recent East Germany and then moved to Polish and Czech history. These two receive more attention in his volume than Southeastern Europe and the post-1945 chapters concentrate on the members of the Soviet Bloc, thus limiting coverage of Yugoslavia and Greece. The extensive past publication of Bideleux and Jeffries spans the last Communist years into the post 1989 period, concentrating respectively on politics and economics. Unlike Connelly, they provide separate sections for Southeastern Europe the region and East Central Europe up to the First World War. They also focus on state structures from the Roman and Byzantine Empires forward into the modern era, a useful com- 
plement to Connelly's emphasis on the nation. Following both approaches along with Calic's through their long general accounts to their specific references to Serbia offers a broader and less pejorative picture of its history than in some current Western historiography. Those references understandably decline during the time of the two Yugoslavia's, particularly after 1945 when the Cold War definition of Eastern Europe meant the Soviet bloc minus Yugoslavia and also Greece.

\section{0-1815}

This first millennium receives more space from Calic and Bideleux and Jeffries than from Connelly. He recognizes the early appearance of Serbs and Croats in the late seventh century and the first recorded evidence of their presence by the ninth century. On Croatia, Calic points out that no original copy remains of the Pacta Conventa of 1102 with Hungary to confirm dependence or autonomy. Little detail describes the rise of the Serbian polity from the thirteenth century under the Nemanjas to Tsar Dušan's larger, putative empire. The prior conversion to Christianity, the Serbian monastery at Hilandar on Mt. Athos, and the emergence of Kosovo as the Serbian religious and cultural center are however fully noted. The Kosovo cycle of folk poetry commemorating the 1389 battle is however left as a religious myth that was only later transformed into a national one after the First Uprising in 1804 (p. 261). Connelly calls that connection one already preserved over the centuries in folk singing played with the gusle in villages. Literacy was not needed as he notes to mobilize a national movement without the Enlightenment figures like Dositej Obradović and the linguist Vuk Karadžić that Calic emphasizes. Bideleux and Jeffries point instead to early connection of state and society under the framework of the Orthodox church and the Byzantine Empire. They find a relevant legacy for Serbia of "vertical power relations and structures" in the decision of Stefan Nemanja to abdicate his ruling position in 1296 and become a monk in the subsequently autocephalous Serbian Orthodox Church, leaving his son to call himself Serbia's "first crowned king" and his brother, later Saint Sava to expand the church's authority. His successor Tsar Dušan expanded the Serbian monarchy into an empire to rival and perhaps succeed the Byzantine Empire. This common framework for national and religious identity contradicts Calic's contention that only religious myth was left to fuse with a Serbian national identity that only emerged after the First Uprising. Such vertical authority of state and reli- 
gion would prove a later burden to the independent Balkan states but an advantage in their initial insurrections (p. 122).

The Ottoman conquest and its long regime came first, also based on vertical authority. Calic covers the conquest after brief reference to the Kosovo battle in 1389 to provide a full account of the later Albanian resistance under Skenderbeg. We see his connection to Dubrovnik and then the first of the city sections, the Albanian port of Krujē in 1450. An initial Albanian migration to Italy from there and elsewhere followed Skenderbeg's defeat in 1478. The Dalmatian explorer, Marco Polo, whether Venetian or Croatian, had already recoded his travels to the wider world two centuries earlier. After the Ottoman capture of Belgrade in 1521, we see the major figure of the subsequent regime as the Bosnian Grand Vizier Mehmed Pasha Sokullu who authorized a Serbian orthodox Patriarch in Peć in 1557 to replace the Bulgarian seat in Ohrid. Her failure to identify Sokullu as a Serb converted under the devshirme levy of children should be noted. At the same time, the Vlach conversion to Orthodoxy and later Serb assimilation is affirmed. More importantly for Ottoman history, the rise of separate ciftlik holdings by Ottoman cavalry in the seventeenth century came less from the attraction to Mediterranean trade cited by Calic and more from the failure of the Ottoman central authority to prevent distant Balkan officers from taking over the non-hereditary share of Sultan's land they had been given as timar only to occupy and take a small share of its produce for themselves. By the eighteenth century, the Ottoman response particularly in Serbia and Greece was to designate local family leaders or clergy as ayan to collect revenue due the central authority, not as in Wallachia and Aegean Macedonia whereas Calic is correct in ascribing such rights to the highest bidders in a capitalist competition for access to international trade (p. 181). In Serbia it was the interior ayan displacement by Turkish janissary foot soldiers, themselves displaced from Constantinople by Ottoman military reforms, that provoked the First Uprising in 1804. Bidleeux and Jeffries provide the better guide from recent Turkish and Western scholarship to changing Ottoman policy to secure and control its largely rural Balkan lands. They track the range of opinion on the rural regime, naming the relevant historians. But their account then falls silent on the First Uprising itself.

Cities and towns are the surer ground for Calic's approach. She rewards the reader with valuable sections on Constantinople (Istanbul) in 1683 and Ragusa (Dubrovnik) in 1776. With a population over 700,000, she calls the Ottoman capital "the most important Eastern metropolis of 
the seventeenth century" (p. 123). International trade was in the hands of Greeks, Jews and Armenians among a wider multi-ethnic population. Commercial contacts reached to the rising Atlantic economy beyond the Mediterranean. These links brought corn, potatoes and tobacco to the region, while cotton came from Egypt. Scholarly interest in the wider world was reflected in the pioneering geographies of Katib Çelebi. Ragusa was far smaller, some 4,000 inside the walled port, and less multi-ethnic. Largely Croatian and Catholic, Calic records the migration of only a dozen Bosnian Serb families in the seventeenth century. Their request to build an Orthodox Church was denied, unlike the request of the Jewish residents for a synagogue. But the city's ruling elite spoke Italian and oversaw a larger commercial fleet than Venice's. Their trade reached to North America and cultural engagement to the French-led Enlightenment, especially after the banning of the Jesuit Order in 1773. Claimed by Calic as the first one, a printing press set up in 1783 was indeed one of the first in the future Yugoslav lands. Like Marco Polo and Çelebi, Dubrovnik's Rudjer Bošković is presented as evidence of the region's links to the wiser world. The young physicist soon left his Croatian origins and some brief Jesuit training in Rome far behind him. Participating in scientific societies in Vienna, London and Paris, he was a French citizen by 1776. He even entertained plans to visit the new American republic.

Elsewhere in her chapter on the early modern challenges to the aging empires dividing the entire region, Calic takes note of Venetian Dalmatia and its struggles with the uskok banditry and piracy from its upland border with the Ottoman Empire. But she neglects the Habsburg Military Border with its mixture of Serbs and Croats attracted by land grants for military service. Instead, we learn of a brief effort in 1745 by the larger Croatian landowners to draw Slovenia and still Venetian Dalmatia together in a Triune Kingdom under the Habsburgs. Not neglected is the large Serb migration from Ottoman Kosovo and Serbia following the Habsburg defeat in 1688. Their movement into what became the Habsburg Vojvodina in the eighteenth century receives more attention than the German migration, also encouraged by Vienna to deny Hungarian penetration. Vojvodina also serves as a base for the key figure of the Serbian Enlightenment, Dositej Obradović. Calic lauds his knowledge of some eight languages but notes his emphasis on a writing a naive language to correspond to the spoken language. Less well known is the interest in Enlightenment reforms she finds from leading Serbian Orthodox and Catholic Croat clergy in Vojvodina and Slavonia. 
With what Calic calls the global revolutions in America and France, her account is again joined by Connelly's volume. They cite Austrian military training from the 1790s forward for giving some volunteers from Ottoman Serbia and well as from Vojvodina valuable training in expanding their initial revolt in 1804 to reject Ottoman authority entirely. Calic cites some interest under Karadjordje's leadership of receiving Austrian assistance but does not mention the larger effort to win support from Tsarist Russia. No troops ever arrived but, as is well known, and it was the diversion of the Russo-Ottoman war allowed the First Uprising to survive until 1813. Beyond the earlier Austrian military experience, Connelly explains the 1804 revolt's spread and survival primarily by the unifying force of a Serbian identity preserved as noted above from the Kosovo cycle, not simply a religious identity. He compares the Serbian insurrection with Polish resistance to the three partitions of the late eighteenth century. In his Conclusion (p. 797), Connelly uses the Serbian case to reject both literacy (Benedict Anderson's print capitalism) and an established state structure (John Stuart Mill) as prerequisites for national identity.

\section{5-1945}

The model of nation-states set by the independent Balkan states in the nineteenth century and the independent states covering all of Southeastern Europe in the interwar period receives surprisingly little attention from all three volumes. So does the First World War. Greece is barely mentioned, and the domestic dynamics of the pre-1914 monarchies neglected.

Calic includes the Greek struggles for independence into the 1830s in her chapter on Global Revolution, but for a city she chooses still-Ottoman Thessaloniki in 1821, with Greeks a small minority in its multi-ethnic populationand a plurality of Sephardic Jews the international port's major merchants. For her chapter to 1878, Nations toward State, she avoids the national capitals emerging in Belgrade or Athens and picks Plovdiv, still-Ottoman in 1876 and another multi-ethnic hub for international trade. We find no reference to progress in the domestic administration of autonomous Serbia since the autocratic Miloš Obrenović in the 1830s. His taxfree land grants are acknowledged for the large number of Serb immigrants they attracted. Romanian reforms under Cuza in the 1860s, with no mention of their origin in the Russian regime in the 1830s, are acknowledged. For Serbia, the French-inspired modernization of domestic administration under Prince Michael Obrenović are not. Instead, we read only of the expulsion of Muslims, actually Turk troops in the fortresses, and 
the Prince's effort to form a large army and unite with Greece confronting the Ottoman Balkans. Here we find the familiar appearance of Foreign Minister Ilija Garašanin's Načertanije, drafted in 1844 to claim the widest Serb-inhabited lands for Serbia. She mentions its origins in a Polish dissident's document that spoke only of South Slav lands, but as the post-1989 scholarship and polemical articles on Serbia do not, adds that Garašanin's vision also accepted the Croatian Illyrian idea of Serbs and Croats as one people (p. 263). Seeing early signs of the Yugoslav idea, she praises the Serbian liberal leader of the 1870s Vladimir Jovanović as well as the Vojvodina Serb Svetozar Miletić and the early socialist Svetozar Marković for similar transnational sentiments. Their principal advocate was of course the Bishop of Djakovo in eastern Slavonia, Josip Juray Strossmayer. Rejecting the new Catholic doctrine of Papal infalibility, he foresaw Orthodox accommodation with Serbia and left a legacy to Yugoslavism that Calic sees as already spreading in the last third of the nineteenth century.

As for Yugoslavism, Connelly makes the useful point that Ljudevit Gaj's ideas and his writing on Illyrianism were harder to understand for the general public than Vuk's translations from folk poetry (p. 156). Otherwise, his account of the nineteenth century pays no attention to the internal dynamics of the independent Balkan states. We follow instead the 1867 Ausgleich between Austria and Hungary, the subsequent Nagodba of Hungary with Croatia, and the 1878 Berlin Congress to see the interplay of Great Power motives and opinions. Dismissive remarks in Berlin about the backward Balkan peoples are cited from Bismarck and Disraeli. His subsequent section on The New Nation States recognizes their independence but focuses instead on the Austro-Hungarian occupation in Bosnia-Herzegovina that replaced the long Ottoman regime. Against the death or departure of 200,000 Bosnian Muslims and some Turks in the warfare and disruption from 1876 to 1878 , he notes the subsequent arrival of Croat officials and merchants. The entire chapter in Bideleux and Jeffries on The emergence of the Balkan national states, 1817-1913 is barely 10 pages long. No states are mentioned by name, but an informed set of subsections address merchant capitalism, the plight of the peasantry, population growth and migration. They favor the Balkan states over Egypt and the Ottoman Middle East in the retardation debate about relative backwardness. One brief subsection on Weak States and Pervasive Corruption dismisses and evidence of political reform, still burdened with the vertical authority the authors trace back, as noted above, to the Byzantine legacy (p. 122). 
Calic's chapter calls the period from the Congress of Berlin in 1878 to 1912 Imperialism and Crisis. Its dynamics move forward on globalization fed by Great Power imperialism and expanding Balkan trade and cultural connections. The Austro-Hungarian occupation of Bosnia-Herzegovina is presented as the same sort of colonization as practiced by the Great Powers in Africa and Asia. But the struggle between Vienna and Budapest over a connecting rail line is a better example of Austro-Hungarian rivalry than colonial interest coal and iron ore mines of which the monarchy had no need. Taming that rivalry also explains the Austrian decision to impose tariff and export restrictions on Serbian livestock in 1906 to assuage Hungarian livestock interests, as long detailed by Dimitrije Djordjević (1962), Instead she calls King Peter's decision to initiate the tariff war to free Serbia from its economic dependence on the monarchy (p. 323). Growing foreign trade for Serbia and the other independent state is praised as part of globalization, despite its being confined to Europe It is also condemned as a part of peripheral dependence and growing global inequality. With no statistical evidence provided, we are given only the testimony of international and transnational politics as provided by the Serbian socialist party's 1910 conference in Belgrade and the Croato-Serb coalition. It won the leading position in the Croatian Sabor in Zagreb by 1906, prevailing over the Party of the Pure Right which is criticized by Calic for its exclusionary nationalism. The Serbian Radical Party of Nikola Pašić is rightly linked to narrow nationalism. But calling its Narodna Odbrana to promote the Serb cause in Bosnia a paramilitary organization from 1894 conflates it with the Union or Death organization of Serbian military officers from 1911. She does praise the civil rights and free press from the 1903 Serbian constitution under Petar Karadjordjević as a constitutional monarch. Citing Olga Popović-Obradović (1998) to dismiss the legitimacy of the prewar parliament entirely, she fails to consult the case made by Dubravka Stojanović (2003). Acknowledging corruption, she notes the promising two-party system that first emerged and the parliamentary coalition of 1909 that survived, albeit Radical led, after the 1906 tariff war and the Austro-Hungarian annexation of Bosnia-Hercegovina in 1908.

Turning back to the cultural and social history that is the volume's major contribution, Calic examines wider international connections and perceptions of Southeastern Europe. First a section on technology and communication traces the career of Nikola Tesla from a Serbian priest's family in Croatia to an electrical engineer in the United States whose discoveries rivaled those of Edison, if alas not his business sense and corporate con- 
nections. Next come Fan Noli's early years as a student and priest in the United States before emerging briefly at the head of an elected Albanian government in 1924. Calic calls attention to numerous other immigrants from the Austro-Hungarian borderlands not only to the pre-1914 US but also to Vienna, Budapest and Prague. Colonization or Perceptions focuses on the role of international exhibitions lime the Paris World's Fair of 1900 in Imagining the Balkans, the title of Maria Todorova's pioneering work (1997) as showing the region as unconnected to the modern world. The Serbian exhibition did its part by showing only representations of Tsar Dušan and the Kosovo folk poetry. Others presented folk dancers in village holiday dress. But in Balkan capitals, Branislav Nušić in Belgrade and Aleko Konstantinov in Sofia are nonetheless credited with their satire that satirized the urban and official pretentions of newly important people.

In her next city section, Belgrade 1913, she acknowledges the rise of a large professional class, an appreciative modern audience for such humor. State officials and merchant property owners also occupied a European-looking city center, with no mention of the former far outnumbering the latter. The city's atmosphere in August 1913 is rightly called celebratory after victory in the two Balkan Wars and the annexation of Kosovo and Macedonia. But we see the socialist leader Dimitrije Tucović free to criticize the military rule and lack of citizens' rights for Macedonians and Kosovo Albanians. The dissident writer Isidora Sekulić used her journal Slovenski jug to advocate a multi-ethnic Yugoslavia rather than a Greater Serbia. Its often presumed advocate Jovan Skerlić is credited with advocating a compromise between the Serbian and Croatian languages. We read of scholars in Zagreb and Belgrade at work on a common Yugoslav encyclopedia. She frames the Bosnian Serb Gavrilo Princip's trip to Belgrade to receive the army pistol he used to assassinate the Archduke Ferdinand in Sarajevo against the opposition of the Pašić government to the Black Hand officers who were terrorizing non-Serbs in Macedonia and Kosovo. Here and elsewhere, the only bias in her account favors the Yugoslav idea and wider international connections over any of the narrower nationalisms and their ideals for a nation-state.

Moving from the two Balkan Wars to the First World War, only Calic spends a few sentences on the experience of Serbia under Austrian and Bulgarian occupation. She lists in her bibliography but does not reference the definitive work of Andrej Mitrović $(2004,2007)$. She acknowledges the heroic retreat of the Serbian army to Corfu. Yet neither her volume nor the other two even mention the army's presence at the Salonika 
Front or its role barring the Italian advance in 1919. They do all spell out the Austrian determination to punish "the snake Serbia" in 1914 (Calic, p. 393). After justifiable criticism of the Serbian treatment of non-Serb civilians in Macedonia and Kosovo, she questions as unproven the Austrian case against the Pašić government for the assassination of Franz Ferdinand. Connelly's chapters simply jump from 1914 to 1919. Bideleux and Jeffries examine the various consequences and costs of the First World War but only as falling on the Habsburg monarchy and bringing it down.

The domestic politics of independent states now covering the region in the 1920 s receive only summary treatment. Connelly pays their struggles in the Yugoslav Kingdom more due than the other two. He compares dismissive Croatian attitudes toward Serbia to Czech presumptions over Slovaks, both posing problems for the new Yugoslav and Czechoslovak states. Like Bideleux and Jeffries, he dismisses Wilsonian self-determination as a delusion for multi-ethnic states. He tracks the confrontations of Stjepan Radić and his huge Croatian Peasant Party (HSS) with the Radicals of Nikola Pašić but also records Radić's efforts with others in Belgrade to find some form of accommodation. Connelly records his hope to find an Austro-Hungarian Ausgleich for Croatia without skepticism and then points to his successor's warm welcome to Belgrade in 1938. Calic simply notes "the Croatian question" (p. 403) as a major obstacle for the Belgrade government but moves on to the rest of the region after less than one page. Brief references come later to Radić's assassination in 1928, King Alexander's resulting recourse to the Royal Dictatorship, and then to Alexander's own assassination in 1934. There is no mention of Yugoslavia's bilateral relations with France, Great Britain and Italy, much explored by Belgrade historians before and after 1989. Her next section reviews instead the international and multinational efforts for regional reform and reconciliation in the 1920s. We see the efforts of the League of Nations, the International Labor Organization and the Green International of peasant parties. Communist parties are cited only as a Soviet-led group in the failed attempt at a Balkan Federation in the 1920s and in the Cominform's Popular Front from 1934, identified curiously as anti-League of Nations and not with the anti-fascism that led to their prewar revival. On the Globalization of the Great Depression, the sharper drop in exports than imports from falling agricultural prices is said to set them further behind the developed economies. Fair enough, although no notice is taken of peasant and international debt relief or the industrial advances of the late 1930s. For Yugoslavia, we see only its recourse to the favorable prices and clear- 
ing agreements offered by Hitler's Germany, exaggerated for 1938 by using the higher 1939 figure that included the Czech contribution.

More comfortable with cultural than with economic history, Calic's treatment of Cultural Deglobalization moves from the mushrooming international film industry (who knew that Tarzan's star Johnny Weissmuller was a Banat Swabian?) and transcontinental football loyalties to the spread of Zionism and Pan-Islamic ideology. But she also tracks a retreat from wider European identities or values. The Serbian Orthodox cleric Nikolaj Velimirović led a dismissal of the Enlightenment and European modernism in favor a religious revival around St. Sava. Connelly and Bideleux and Jeffries are concerned instead with the rise of fascism in the region. They find their example in Romania with its Iron Guard and the Croatian Ustaša, noting that the fascist trappings of the later Stojadinović government did not lead to a fascist regime. Calic examines the Romanian case in her last city section, Bucharest 1939, another prewar capital like Belgrade 1913. As Connelly does for Ljotić, she points out the limited public support for the Ustaša in Croatia, far less than the Iron Guard's.

It is Connelly rather than Calic that provides a full account of Belgrade's prewar politics, the Serbian military coup and the German invasion in 1941, followed by Chetnik and Partisan resistance to the occupation. He acknowledges Ljotić's Zbor as the one prewar fascist movement in Serbia but emphasizes its failure to attract any mass support (p. 424). His more detailed account of the subsequent events in 1941-42 is marred only by pushing the collaborationist regime of General Milan Nedić back from August to the start of the occupation and the anti-Jewish decrees of May 1941 (p. 480). Unlike Calic, Connelly identifies the author of the controversial Moljević memorandum of 1941 proposing a purely Serb Bosnia as a Bosnian Serb lawyer, not the only spokesman for Mihailović. He correctly calls the Chetnik command under Draža Mihailović uncoordinated and unable to prevent its units in Bosnia or Montenegro from committing war crimes or collaborating with Italian forces against the Croatian Ustaša (pp. 454-46). Calic cites later Chetnik collaboration with the Germans against the Partisans as the reason that the British SOE changed its support to the Partisans in late 1943 (p. 463), ignoring the earlier decision in London to back the more active Partisan resistance. Connelly also ignores it. Neither of them cites the most authoritative source from Anglo-Serbian scholarship, based on participant interviews (Pawlovitch, 2008).

For the rest of the war, all three books harshly criticize the Independent State of Croatia (NDH) and its Ustaša leadership, detailing its war 
crimes and killing of Serbs. Bideleux and Jeffries track the Jews killed by the Germans as well, while Calic lists Bosnian Muslims killed by Chetniks. She does however revise her earlier account of the Partisan numbers to acknowledge a Serb majority in 1944 of 53 percent, versus 19 percent for the late Croat numbers, 9 percent for Slovenes, 6 percent for Montenegrins and half that for Bosnian Muslims and Macedonians (p. 463). Both Calic and Connelly credit the late Partisan success to Tito's military leadership and its multi-ethnic membership. She adds that some 100,000 women were serving in what became the huge Partisan force of 900,000 by late 1945. Only Bideleux and Jeffries even mention the Greek resistance and the ensuing civil war between the Communist-led ELAS and the smaller Republican League EDES linked to the royal government in exile in Cairo. All three ignore the Yugoslav government in exile in London and the charges of Partisan war crimes against Croats and Slovenes as the war ended.

\section{$1945-2015$}

Readers will find even more Serbian subjects ignored or briefly treated as the books move past the Second World War and then the Communist collapse in 1989. For the two histories of Eastern Europe, this is understandable. Their authors' original interests were based on the postwar Soviet Bloc, which only briefly included Yugoslavia. Connelly spends a few sentences on the initial Yugoslav allegiance to the Soviet Union and its federal model for multi-ethnic republics with a single ethnic name. Its experience does not appear again until after the Tito-Stalin split, blamed solely on Tito's interest in leading a Balkan Federation. A fair account follows of the wider decentralization minus central planning but under party-led workers self-management through the 1950s, up to the ambitious market-based reforms of 1965. But the boom of the early 1960s is not tied to inflationary wage increases and easy access to bank credits, as it should be, but instead to the bizarre claim that US financial aid was responsible for nearly half of Yugoslav investment for 1950-65 (p. 566). A majority of the one billion dollars of non-military aid went either to food deliveries or the coverage of current account deficits (Lampe, Prickett and Adamović, 1990). Bideleux and Jeffries only briefly review the Yugoslav economy and self-management but reach further from the 1950s into the 1980s (pp. 498-501). We see tourism and guest worker remittances joined by greater enterprise independence after the fall of the "Serb security chief" Aleksandar Ranković in 1966 boosting growth rates until then slowing after 1974. Increasing regulation and negotiation under the OOUR's are 
identified as burdens but not the 1974 constitution and its boost to the republic SKJ parties.

Calic also neglects the changing balance of power within the set of republic Communist parties. The Serbian complaints about Soviet joint companies as a factor in the Tito-Stalin split and the leading role of its Serbian leadership in the pressure for economic reform in 1965 are absent. Tito's interest in a Balkan Federation is again blamed for the split with Stalin. As for self-management, its original framework under Edvard Kardelj is said to permit the "market economic principles and private companies" (p. 478) that only appeared in the late 1980s under the last reforms of Ante Marković.

Here section on the Cold War moves quickly away from the rest of the region to the Tito regime's Western and Soviet relations to the Third World and the Non-Aligned Movement (NAM). Often neglected in other scholarship, Yugoslavia's charter membership is tracked from its origins in Tito's trip to South Asia in 1954to its leading role after hosting the NAM's 1961 conference in Belgrade. We are invited here to see it as an alternative for the "Global South" to a UN dominated by the US and its Western allies, (p. 487), and the global participation and reputation of Yugoslav experts did indeed spread in the process. The regime's decision to recognize the separate identity of Bosnian Muslims as a "constituent nation", backdated to 1968 instead of 1971, deserves the credit given for expanding projects and connections with Arab and Muslin states. Hostile to any exclusionary ideology, Calic then criticizes the Muslim Brotherhood founded in Egypt and the Islamic Declaration written by Alija Izetbegović in 1970, later prosecuted in 1983 before reemerging to political leadership after 1989. She focuses instead on the SKJ's Džemal Bijedić, an opponent of Muslim separatism and Yugoslavia's Prime Minister in 1971.

More positive views of the Second Yugoslavia follow in her subsection Cultural Exchange and Global Civil Society. The wider connections range from membership in UNESCO to 4 million television sets in use by 1978. The West European link to Eurovision might have been mentioned. But we do read of the freedom to travel as well as work there and the flood of Western tourists to Dalmatia in particular. There was also the expansion of political dissent in the Belgrade journal Praxis and elsewhere to connect West German social democracy and Marxism. But Calic's less positive view not of Yugoslavia but of globalization comes clear in her account of the 1980s and beyond in Global Consumption and Global Crisis. While acknowledging the rising habits of West European consumption in 
Yugoslavia, she ties its debt crisis and others in the region to trade deficits accumulating unfairly across the Global South and to borrowing needed to cover them, and for our region rising military expenses. Missing are the problems accumulating in Yugoslavia's self-managed enterprises sustained by bank credits and social contracts, covered here by Bideleux and Jeffries and others from Harold Lydall (1989) forward.

Nor do her subsequent sections of Sarajevo 1984 and 1989 and After recognize the decisive role of the republics' largely autonomous Communist parties in the withering away, as dubbed by Dejan Jović (2009), to a central government reduced after Tito to the SIV or Federal Executive Council and its Chair. Instead, the dissolution of Yugoslavia after 1989 is ascribed to globalization as "the opening to the world market only exacerbated regional disparities" (p. 527). The well known gap between Slovenia and Kosovo is cited. Renationalization from "politicians and intellectuals" followed, confounding a popular majority before 1989 that considered themselves as primarily "Yugoslav citizens" and "the whole Yugoslav state as satisfactory or good' (p. 519). The actual dynamics of the resulting wars of Yugoslavia's dissolution are described less debatably, in much the same terms and detail as Connelly. She usefully emphasizes the expanded role of the international media in treating the conflict as a global issue as well. The same sort of globalization accompanied the transition of the International Criminal Court for Yugoslavia into wider proceedings for war crimes elsewhere.

Bideleux and Jeffries provide the most informative account of the struggle with post-1989 economic transition in the 1990s and the subsequent aspirations for EU membership in their separate sections for Southeastern Europe. They make a case for gradualism rather than neo-liberal Shock Therapy or sweeping privatization applied only in Poland. They find the funding and prospects for EU membership after 2000 more promising than the meager Western assistance provided before then. Their conclusion praises the EU as a confederal association, "the most fully fledged example" of the needed supranational framework of law and rules (p. 619). Serbia's experience is not neglected, as it included in statistical tables absent in Calic and limited in Connelly. For Serbia, their tables show the relatively large advances in GDP, lower rates of inflation and comparably high unemployment in the pre-2008 boom than the other successor states.

As elsewhere in this chapter, Calic concentrates on the Western Balkans in her final section, Southeastern Europe in the Global Present. For Serbia, we see the same criticism of international trade disparities ad a 
neo-liberal financial framework applied equally to the last years of Yugoslavia and the transition of the 1990s. No notice is taken of the large "socially owned" enterprises that survived privatization in Serbia in particular and counted heavily against the transition to a market economy. We are only told that Shock Therapy was not tried in all of the region, as it never was in Serbia, and failed where it was (p. 539). Her emphasis moves from the initial "prosperity gap" in income with Western Europe and pre-1989 Yugoslavia to its persistence nearly 30 years later. Both the hard recovery of the 1990s and hard times after the West's 2008 financial crisis are laid to neo-liberal oversight by the World Bank and the IMF rather than any domestic policies. Yet she is more optimistic in her Conclusion than Connelly's about the EU and prospects for regional membership. He worries about narrow nationalism persisting over lost borders even among members like Hungary (p. 800). Calic does not worry about such claims. Quoting Mark Twain's wry remark to Nikola Tesla, history does not repeat itself, it only rhymes. Reiterating her appreciation of multinational connections, she cites rising national incomes in new EU members and public sentiment that remains pro-European in the applicants. (p. 561).

The strength of Calic's book and its case for a global framework remains in social and cultural history. She points to the transnational consequences of the large emigration from the successor states and Albania, as well as Bulgaria and Romania, with high percentages still expressing the desire to emigrate. She fairly states that "Global civil society has a greater presence in Southeastern Europe than ever before": (p. 544). Credit is given to the Soros-funded Open Society Foundation and could be extended to the many other Non-Governmental Organizations that have persevered in Serbia and elsewhere. Her sympathy for the successor states and their rule by ethnic majority is harder to find. Criticism of the excesses are hardly confined to Serbia. And looking back to the former Yugoslavia, she praises the welcome in Belgrade that Emir Kustirica's film on Communist persecutions and prisons after the Tito-Stalin split, Otac na službenom putu, after being banned in Sarajevo. As an aside, when I saw this film shown there in 1987, the largely young Belgrade audience was puzzled by and amused by seeing a country of which they had no knowledge or memory. Calic does not mention his later, more controversial 1995 film Underground, based on Dušan Kovačević's novel Bila jednom jedna zemlja. It showed Yugoslavs of the 1960s later fighting each other in the wars of succession. But when they reconciled at a fantasy ending on an island floating away, much of my Belgrade audience was crying. If they were missing 
the lost Yugoslavia, I cannot fairly say that we see such Yugonostalgia in Calic's last chapters. But I do see some regret, which I share. Finally, judging from her book and also in my opinion, Yugoslavia was not just part of Southeastern Europe or Eastern Europe. It was part of Europe, and Belgrade has been a European city for more than a century.

\section{Summary}

Calic's book receives the greater attention not only for its narrower regional focus but also for its application of the new global history and its emphasis on transnational connections. Her book revolves around the social and cultural history central to this approach. Belgrade 1913 is one of nine cities, typically trade centers, treated in instructive separate sections. Connelly covers a good deal of the missing political history until focusing on the Soviet bloc after 1945; Bideleux and Jeffries concentrate instead on economic history, domestic and foreign, from the early modern period through the 1990s. Within their three respective concentrations, Serbian history is fairly treated, including the Second if not the First World War.

\section{Sources and Literature}

- Calic, Marie-Janine. Socialgeschichte Serbiens, 1815-1941. Munich: R. Oldenbourg Verlag, 1994.

- Đorđević, Dimitrije. Carinski rat Austro-Ugarske i Srbije, 1906-1911. Beograd: Narodna knjiga, 1962.

- Gligorijević, Branislav. Parlament i političke stranke u Jugoslaviji, 1919-1929. Beograd: Institut za savrmenu istoriju, 1979.

- Jović, Dejan. Yugoslavia, A State that Withered Away. Lafayette, Ind: Purdue University Press, 2009.

- Judson, Peter M. The Habsburg Empire, A New History. Cambridge, Mass: Harvard University Press, 2016.

- $\quad$ Lampe, John R. Balkans into Southeastern Europe, 1914-2014, A Century of War and Transition. London: Palgrave/Macmillan, 2014.

- Lampe, John R., Russel O. Prickett, Ljubiša Adamović. Yugoslav-American Economic Relations, since World War II. Durham, NC: Duke university Press, 1990.

- $\quad$ Lydall, Harold, Yugoslavia in Crisis. Oxford: The Clarendon Press, 1989.

- Mitrović, Andrej. Serbia's great War 1914-1918. London: Hurst, 2007 (2004 in Serbian).

- $\quad$ Okey. Robin, Taming Balkan Nationalism, The Habsburg Civilizing Mission in Bosnia, 1878-1914. Oxford: Oxford University Press, 2007. 
- Pawlovitch, Stefan. Hitler's New World Order, The Second World War in Yugoslavia. New York: New York University Press, 2008.

- $\quad$ Stavrianos, Leften. The Balkans since 1453. New York: New York University press, 2000, (1958).

- Stojanović, Dubravka. Srbija i demokratija, 1903-1914. Beograd: Čigoja, 2003.

- $\quad$ Stojkov, Todor. Vlada Milana Stojadinovića, 1935-1937. Beograd: Institut za savremenu istoriju, 1985.

- $\quad$ Smith, Helmut Walser. Germany a Nation in its Time, Before During and After Nationalism, 1500-2000. New York: W. W. Norton, 2020.

- Todorova, Maria. Imagining the Balkans. New York and Oxford: Oxford University Press, 1997. 


\title{
Резиме
}

Џон Р. Лемпи

\section{Србија и југоисточна Европа између глобалне и источноевропске историје}

\begin{abstract}
АПстрАкт: Ослањајући се на пола века истраживања и објављивања радова о Балкану, која су започета у Београду, Џон Лемпи приказује три нове студије овог региона и њихов осврт на Србију из пера истакнутих западних историчара. Мари-Жанин Чалић из Немачке бави се искључиво југоисточном Европом, док Конели из САД-а и Бидело и Џефрис из Велике Британије у својим књигама о источној Европи обухватају и Балкан.

КљУчнЕ РЕчи: Србија, Југославија, југоисточна Европа, глобална историја, регионална историја, Мари-Жанин Чалић, Џон Конели, Робер Бидело, Јан Џефрис
\end{abstract}

Књизи Мари-Жанин Чалић посвећена је већа пажња, не само због њеног ужег регионалног фокуса већ и због примене нове глобалне историје и истицања транснационалних веза. Њена књига фокусира се на друштвену и културну историју, која је централна за овај приступ. Београд 1913. године један је од девет градова, типично трговачких центара, који су обрађени у поучним засебним одељцима. Конели обухвата велики део политичке историје, да би се коначно фокусирао на совјетски блок после 1945. године; Бидо и Џефрис се, с друге стране, концентришу на економску историју, домаћу и инострану, од раног модерног периода до 90-их година. У оквиру своје три теме, ове књиге коректно обрађују српску историју, укључујући Други, а донекле и Први светски рат. 